\title{
Discussion
}

\section{Discussion about the articles by E Lahde et al in Ann Sci For (1994) 51, 97-120: "Structure and yield of all-sized and even-sized conifer-dominated stands on fertile sites" and \\ "Structure and yield of all-sized and even-sized Scots pine-dominated stands"}

\author{
by Pierre Duplat
}

(Office national des forêts, département des recherches techniques, 77306 Fontainebleau, France)

I have some reservations about 2 papers by $\mathrm{E}$ Lähde et al in Annales des Sciences Forestières (1994) 51, 97-120, entitled: "Structure and yield of all-sized and evensized conifer-dominated stands on fertile sites" and "Structure and yield of all-sized and even-sized Scots pine-dominated stands".

I will express the most important ones referring to the first paper, the second one using the same methodology.

\section{INTRODUCTION}

The material used comes from the third national forest inventory 1951-1953 in southwestern Finland, on Myrtillus type sites or more fertile ones: temporary plots, 1000 $\mathrm{m}^{2}$ in size, inventory by species and diameter class starting from the $2-6 \mathrm{~cm}$ class, measure of dominant height (100 largest trees/ha), and estimation of current volume increment over the 5 preceding years (by boring every tree?).
Each plot is considered as a stand, with its inventory, its total stem volume (tariff function(s)?), its dominant height and its total stem current increment.

Precise criterions, applied to the allspecies diameter histogram of each stand, make it possible to decide whether it belongs to 1 or the other of 2 groups of "structure": "all-sized" and "even-sized"; $83 \%$ of the stands may thus be classified in 1 or the other group, and constitute the material for the study.

The stands belonging to each large group of structure are classified into 2 groups of "composition", depending on whether they include less or more than 120 broad-leaved trees per hectare: "coniferous", "mixed".

The "yield" of each group structure x composition is judged on the basis of 2 results:

- the mean of current increments for stands with a given standing volume $(137 \leq \mathrm{V} \leq$ $167 \mathrm{~m}^{3} / \mathrm{ha}$ )

- the mean of relative current increments (increment/volume) of all stands in the group. 
An explicit objective of the paper is to come to a conclusion, in this region and on these sites, about which structure, which composition, or which combinations, are better as far as volume yield is concerned.

In my opinion, the method used and cursorily described does not fulfill this expectation; I will explain why.

Current increment of a stand, at a given time, mainly depends:

i) on the quality of the site where it grows

ii) on its specific composition

iii) on its age, if it is an even-sized (evenaged) stand, or on its intimate structure (in ages, dimensions, spatial distribution) if it is an uneven-aged stand

iv) incidentally and the above conditions being fixed, on its standing volume if it falls far below the biological maximum attainable under those conditions.

A first remark is essential: the current volume increment of a stand at a given time is not its long-term yield, especially if it is an even-aged stand. I will come back to that point when examining factor 3 .

Being not too demanding about the definition of the factors and their levels, one can say that factor 2 (composition) and factor 3 partly (large types of structure) are tested factors in the present paper. The other ones - factor 1 (site quality) factor 3 partly (age or intimate structure), factor 4 (volume) - are therefore to be controlled. Let us look at that.

\section{Factor 1: site quality}

Comparisons between types of structure or composition make sense only for a given site quality. In the present study, the material used spreads over a large range of site quality (Myrtillus site type or more fertile); but site quality of the stands is not known, only their dominant height is.
For even-aged stands, dominant height is not a site index by itself, as it depends on age at a given site quality.

For uneven-aged stands, it could roughly by assumed, if the 100 largest trees/ha were more or less at the same stage of maturity in every stand, but nothing ensures that this is the case here. Given the criterions used to classify the stands into groups of structure, it is even likely that the "all-sized" group includes part of the young even-aged stands.

So, site quality cannot be controlled by a consistent index in the present study, where the problem is still further complicated by the presence of several species. Stating that dominant height alone "may give a good base for comparisons of site quality" between stands, whether even-aged or uneven-aged, is not satisfactory.

As this factor is not controlled, correlations may happen between site quality and other factors: it is even likely for the "composition" factor, with broad-leaved trees being noticeably present upon certain site types rather than upon other ones.

\section{Factor 2: composition of the stand}

Composition is explicitly tested as a factor in the paper, considering only 2 levels: "coniferous" and "mixed". Therefore, it should not pose any special problem (apart from the varying proportions of spruce and pine).

However, one reservation must be made: stands are classified into "coniferous" or "mixed" according to a criterion which is an absolute number of stems per hectare; it is less demanding for young (and "all-sized") stands than for ageing ones. So, young stands showing a small proportion (5-10\%) of broad leaves will be classified as "mixed", whereas similar but ageing ones, of whose increment is smaller, will be classified as "coniferous". 


\section{Factor 3: structure and age}

Factor 3 is a composite, hierarchical factor with an upper stage: "structure" ("evensized"/"all-sized") and a lower one: age for "even-sized" stands, intimate structure for "all-sized" stands.

At the upper stage (the 2 groups of structure), it is a tested factor in the paper. But, there too, a reservation must be made. Criterions used by the authors lead to classify young even-aged stands (eg 3000 stems/ha with a mean diameter of $8 \mathrm{~cm}$ ) as "all-sized"; the average histogram of stands classified as "even-sized" shows a lack of young stands. A certain number of such young stands, whose increment is larger than that of aged ones' for the same levels of other factors, reinforced the "all-sized" group.

At the lower stage (age or intimate structure), it is obviously a factor to be controlled. Let us be more accurate: firstly, the "yield" of an even-aged stand is not its current increment which strongly depends on age, but its mean increment over a rotation. Moreover, this one depends on the rotation's duration, which must therefore be fixed, for instance at the average duration implemented actually or at the duration leading to the maximum mean increment. If this mean increment is to be derived from the average of current increments observed at a given date on even-aged stands of different ages, all other factors being fixed, the age distribution of these stands must be uniform over the chosen duration. This is not controlled in the present paper, the age of even-sized stands being unknown.

As for uneven-aged stands, the ideal case is a stand whose intimate structure is kept stationary with enough standing material to avoid any noticeable loss of production, and whose current increment is constant over time: then it is equal to the mean increment. In general, it is very difficult to assess how far one stands from this ideal case, and the issue is not considered in this paper.

\section{Factor 4: standing volume}

It is not the value of standing volume per se that has an effect, even less a linear effect, upon current increment. It acts noticeably, everything else (site quality, composition, age or structure) being fixed, only as it may fall markedly below the corresponding maximum attainable volume. The relevant control variable would be rather the ratio of standing volume to that maximum, but this one is unknown here.

So, would even site quality and age or intimate structure be properly controlled in other respects, there would be little sense to work at a fixed absolute volume (152 $\left.\mathrm{m}^{2} / \mathrm{ha}\right)$. There is no more sense to consider the relative volume increment rate, as though standing volume were a capital proportionally yielding its annual interest. One may refer to Assmann (The principles of forest yield study, 1970, Pergamon Press, pp 229 sq) in this respect.

This use of standing volume is therefore not pertinent when the other factors are properly controlled. One cannot a fortiori hope it becomes relevant when these other factors are not controlled.

\section{CONCLUSION}

"Yield" indicators obtained, with the method and material used in this study, do not seem to be relevant indicators for the reasons expounded here, among which I summarize the main ones:

- confusion between yield and current increment, lack of control of age

- lack of control of site quality

- control of standing volume that is not pertinent

- criterions, used to classify stands into groups, such as the appellations of these groups are not strictly consistent with the nature of the stands included. 
Therefore, these indicators do not allow, in my opinion, a conclusion about the respective yields of all-sized or even-sized and coniferous or mixed stands.

Recently, a colleague from our department (Demolis, 1993, "Étude de l'influence de la fertilité du sol sur le choix du traitement sylvicole des peuplements résineux jurassiens", document interne, département des recherches techniques ONF) conducted a comparative study about even-aged and uneven-aged high forest in the Jura range, on the basis of man- agement records. Studied units were not plots, but whole forests, planned and managed for a long time according to one or the other structure (330 forests, 64000 ha). He found that annual volume increment, during the 10 or 20 years preceding the last revision of the management plan, was distinctly larger in the even-aged high forest group. He wisely did not conclude that the even-aged system is better than the uneven-aged one, but that forests so treated are likely to be standing on more fertile sites on average. 


\section{Reply note to P Duplat's letter: \\ "Yield comparisons among structurally all-sized and even-sized forest stands" by $E$ Lähde, O Laiho, Y Norokorpi, T Saksa}

\begin{abstract}
A long tradition in the Finnish forestry and National Forest Inventories is to apply the forest site type system when classifying forest sites (Ilvessalo, 1951). This classification is based on the ground cover vegetation and it is independent of the growing stock, its age, structure and species composition (Cajander, 1909, 1949; Vuokila, 1980). When comparing structurally all-sized and even-sized (all-aged and even-aged) stands, the forest site type system is more reliable than the site index $(\mathrm{H}$ 100) classification. The reason is that the harvesting of timber in all-sized stands takes place as single-tree selection, which also focuses on bigger trees. The low-thinning in evensized stands focuses primarily on smaller trees. When comparing dominant height after different logging operations on a particular site type, it is shorter in the all-sized stand than in the even-sized stand (eg Sterba and Monserud, 1993). The same applies to tree age when comparing stands with the same history of establishment (Lähde, 1995).
\end{abstract}

\section{INCREMENT CORRELATE WITH SIZE, NOT WITH AGE}

Increment in all-sized stands shows better correlation with size than with age (Cajander, 1934; Sarvas, 1944; Schütz, 1969; Indermühle, 1978). After releasing, the undergrowth trees generally attain the same size as trees which have always been released to grow in (Sarvas, 1951; Vaartaja, 1951; Vuokila, 1956; Klensmeden, 1984). Therefore, the age and height of the dominant trees are not reliable parameters for comparing structurally different stands. The Finnish forest site type system is not influenced by these problems.

The group of the Myrtillus type and more fertile sites (Lähde et al, 1994a; Ann Sci For $51,97-109$ ) in the study material did not demonstrate any bias in favour of all-sized stands; instead, the distribution slightly favoured even-sized stands. The distribution of the study stands by site type and structure class was in order of site fertility as follows (percent of sample plots):

All-sized Even-sized

$\begin{array}{lll}\text { Oxalis Myrtillus type } & 42 & 48 \\ \text { Myrtillus type } & 58 & 52\end{array}$

The similarity of the stands' tree species composition was another reason for combining the fertile site types to form 1 group. The material on pine-dominated stands (Lähde et al, 1994b; Ann Sci For 51, 111120) represented only 1 forest site type (Vaccinium type). It should be noted that southwestern Finland is a relatively uniform region in terms of climate and topography, and thus differs considerably from the mountain regions of Central Europe, for instance.

The dominant heights were presented in the publications for describing stands, but not for classifying site quality due to the aforementioned limitations. Nearly all sample plots also included tree age measurements, but these parameters represented only the average age of the dominant trees. 
The mean ages of dominant trees in the study stands were as follows (fertile sites as an example):

$\begin{array}{llc}\text { Mean } & \text { Standard } & \text { Max } \\ \text { age, a } & \text { deviation } & \text { age, a }\end{array}$

$\begin{array}{llll}\text { All-sized } & 63 & 18 & 126 \\ \text { Even-sized } & 69 & 16 & 130\end{array}$

Thus, the material did not differ any more than might be expected due to the different felling methods because all-sized stands should be harvested before reaching maturity. The general understanding appears to be that more research needs to be done on the subject of site index $(H$ 100) classification for all-sized stands (Andreassen, 1994; Keller, 1994).

\section{EACH SAMPLE PLOT REPRESENTED AN INDIVIDUAL STAND}

It is necessary to underscore the fact that each sample plot represented an individual stand. They were classified according to development stage, site type and structure class in the said publications. Adhering to inventory instructions, a sample plot was moved if it happened to fall on the boundary between 2 different stands (IIvessalo, 1951). Thus, it was not possible for a particular sample plot to contain growing stocks differing in age or otherwise, as is suspected by Dr Duplat. The growing stock on each sample plot was classified separately. The material included only advanced, primarily well- or satisfactorily-managed stands with normal growing stocks; even-sized stands were not classified as being all-sized. The stands were also identical in terms of their history of establishment - ie they were of natural origin.

\section{BROAD-LEAVED TREES AND STRUCTURE INFLUENCE STAND INCREMENT}

Each sample plot was sampled for 10-20 sample trees and these were measured for their 5- and 10-year increments. The publications set out only the 5-year increment data because the differences for the 10year period were similar to the 5-year differences. The sample trees were used in determining the tree increment for each sample plot as a whole. This is often expressed using the concept yield, but more precisely, it is the increment and yield for a particular period.

The criterion used in the publications for sorting out pure coniferous stands and mixed ones was the number of broad-leaved trees. Instead, we could have used, for example, the proportion of the basal area or of volume as recommended by Dr Duplat. Both methods have their weaknesses, however. In further studies, we have examined the dependence of yield on the proportion of broad-leaved trees (in terms of both stem tally and basal area) separately in each structural group. According to these results, it appears that when the proportion of broadleaves increases to about $50 \%$ of the growing stock, stand increment in both structural groups increases and then begins to decrease.

Using the number of broad-leaved trees as a criterion in classifying mixed stands may have caused some bias in favour of the even-sized stands and not the all-sized stands. The explanations for this are as follows: 1) the relative proportion of broadleaved trees in the even-sized mixed stand (because of its smaller overall stem tally) was greater than in the structurally all-sized mixed stand and 2) the broad-leaved trees in the even-sized stand were of greater average size. The same stem tally as the limitation for a pure coniferous stand in both structural groups of advanced forests was 
justified; eg due to differences in the stem diameter distribution, ecological-biological factors (litter etc).

One of the results in our studies was that all-sized stands grew better (with statistical significance) than equal even-sized stands with the equal growing stock volumes. In the material as a whole, the increment of even-sized stands was slightly better than that of all-sized stands when examining stands dominated by spruce; however, this difference was not statistically significant despite the extensive material used. The results covered, of course, only that stage in stand development that the sampling data represented. It should be noted that the growing of even-sized stands (during the rotation) includes regeneration and a fairly long period after regeneration when the annual volume increment is below average. Our subsequent studies dealing with other research material, and also arranged comparative field trials, support the results presented in the publications.

In conclusion, there is an increasing necessity for scientific debate on the subject of stand structure and species composition. This demand involves the international conventions on forest biodiversity and ecological sustainability. The requirement of biodiversity will most probably be extended to the within-stand level, too. When this happens, there will be an even greater demand for scientific knowledge on the functioning of structurally all-sized mixed stands. We wish to express our warmest appreciation to Dr Duplat for the active interest afforded to our research work.

\section{REFERENCES}

Andreassen K (1994) Development and yield in selection forest. Commun Skogsforsk 47, 1-37
Cajander AK (1909) Über Waldtypen. Acta For Fenn 1 , 1-175

Cajander AK (1949) Forest types and their significance. Acta For Fenn 56, 1-71

Cajander EK (1934) Kuusen taimistojen vapauttamisen jälkeisestä pituuskasvusta. Commun Inst For Fenn 19, 1-53

Ilvessalo $Y$ (1951) III valtakunnan metsien arviointi. Suunnitelma ja maastotyön ohjeet. Summary: Third national forest survey of Finland. Plan and instructions for field work. Commun Inst For Fenn 39, 1 67

Indermühle MP (1978) Struktur-, Alter-, und Zuwachsuntersuchungen in einem Fichten-Plenterwald de subalpinen Stufe. Beiheft zu den Zeitschriften des Schweizerischen Forstvereins 60, $98 \mathrm{p}$

Keller W (1994) Standörtliche Inhomogenität von ertragskundlichen Versuchsflächen - eine Ursache von Fehlschlüssen. Schweiz Z Forstwes 145, 1031 1038

Klensmeden U (1984) Stamvis blädning. Några studier på två försöksytor i Dalarna. Examensarbete 1984-1986. Sveriges lantbruksuniversitet. Institutionen för skogsskötsel. Umeả, $38 \mathrm{p}$

Lähde E (1995) Metsää puilta. Vihreä Eämänsuojelun liitto. Hakapaino Helsinki, $112 \mathrm{p}$

Lähde E, Laiho O, Norokorpi Y, Saksa T (1994a) Structure and yield of all-sized and even-sized coniferdominated stands on fertile sites. Ann Sci For 51 , 97-109

Lähde E, Laiho O, Norokorpi Y, Saksa T (1994b) Structure and yield of all-sized and even-sized Scots pinedominated stands. Ann Sci For 51, 111-120

Sarvas R (1951) Tutkimuksia puolukkatyypin kuusikoista. Summary: Investigations into the spruce stands of Vaccinium type. Commun Inst For Fenn $39,1-82$

Sterba $H$, Monserud RA (1993) The maximum density concept applied to uneven-aged mixed-species stands. For Sci 39, 432-452

Vaartaja $Y$ (1951) Alikasvosasemasta vapautettujen männyn taimistojen toipumisesta ja merkityksestä metsänhoidossa. Summary: On the recovery of released pine advance growth and its silvicultural importance. Acta For Fenn 58, 1-133

Vuokila $Y$ (1956) Etelä-Suomen hoidettujen kuusikoiden kehityksestä. Summary: On the development of managed spruce stands in southern Finland. Commun Inst For Fenn 48, 1-138

Vuokila $Y(1980)$ Metsänkasvatuksen perusteet ja menetelmät. WSOY, Helsinki-Porvoo, $256 \mathrm{p}$ 